\title{
Elastisitas Harga dan Elastisitas Pendapatan Permintaan Energi Listrik pada Rumah Tangga di Indonesia
}

\author{
Neila Soraya ${ }^{1 *}$, Bambang Eko Afiatno ${ }^{2}$ \\ ${ }^{1}$ Badan Pusat Statistik Kota Binjai, Indonesia \\ ${ }^{2}$ Program Studi Magister Ilmu Ekonomi, Fakultas Ekonomi dan Bisnis, Universitas \\ Airlangga, Indonesia \\ Email authors: neilasoraya@bps.go.id/afiatno@yahoo.com
}

\begin{abstract}
ABSTRAK
Sektor rumah tangga menempati posisi kedua sebagai konsumen energi terbesar di Indonesia. Listrik adalah energi dominan yang dikonsumsi oleh rumah tangga di Indonesia.Penelitian ini bertujuan untuk menganalisis elastisitas harga dan elastisitas pendapatan permintaan listrik pada sektor rumah tangga di Indonesia dengan menggunakan data mikro Susenas Maret 2018. Alat analisis yang digunakan dalam penelitian ini adalah regresi linear berganda. Hasil estimasi menunjukkan harga listrik berpengaruh negatif terhadap permintaan listrik, sedangkan variabel pendapatan per kapita, ukuran rumah tangga, umur kepala rumah tangga, pendidikan kepala rumah tangga, dan wilayah tempat tinggal berpengaruh positf terhadap permintaan listrik. Koefisien elastisitas harga dan koefisien elastisitas pendapatan menunjukkan nilai yang elastis terhadap permintaan listrik. Hal ini menunjukkan listrik tergolong "normal goods" dan merupakan kebutuhan pokok bagi rumah tangga di Indonesia.
\end{abstract}

Kata Kunci: Elastisitas, Permintaan, Energi, Listrik, OLS

\begin{abstract}
The household sector occupies the second position as the largest energy consumer in Indonesia. Electricity is the dominant energy consumed by households in Indonesia. This study aims to analyze the price elasticity and income elasticity of electricity demand in the household sector in Indonesia using the March 2018 Susenas micro data. The analytical tool used in this study is multiple linear regression. The estimation results show that electricity prices have a negative effect on electricity demand, while the variables of income per capita, household size, age of the head of the household, education of the head of the household, and area of residence have a positive effect on electricity demand. The coefficient of price elasticity and the coefficient of income elasticity show the elastic value of electricity demand. This shows that electricity is classified as a "normal good" and is a basic need for households in Indonesia.
\end{abstract}

Keywords: Elasticity, Demand, Energy, Electricity, OLS

\section{PENDAHULUAN}

Sektor rumah tangga menempati posisi kedua sebagai konsumen energi terbesar di Indonesia (BPS, 2019a). Konsumsi energi pada sektor rumah tangga pada tahun 2014 sebesar 1.349.174 terajoule dan terus meningkat setiap tahunnya mencapai 1.458 .425 terajoule pada tahun 2018 . Rumah tangga, sebagai unit terkecil dalam komunitas, memainkan peran yang penting dalam permintaan karena konsumsinya yang terus meningkat dari waktu ke waktu (Wijaya \& Tezuka, 2013). Penggunaan energi memiliki peran yang sangat penting bagi rumah tangga.Energi merupakan katalisator sehingga rumah tangga dapat merasakan kemudahan dan lebih efisien dalam melakukan kegiatan sehari-hari. Penggunaan energi pada sektor rumah tangga meliputi 
penerangan, memasak, pemanas/pendingin, dan kegiatan rumah tangga lainnya. Selain itu, keberadaan energi juga sangat penting dalam menyokong aktivitas ekonomi rumah tangga.

Listrikadalah energi dominan yang dikonsumsi oleh rumah tangga di Indonesia. Konsumsi listrik sering dikaitkan dengan kehidupan masyarakat modern.Kedepannya, listrik diharapkan menjadi energi akhir yang paling banyak dikonsumsi (Wijaya \& Tezuka, 2013). Listrik yang digunakan oleh rumah tangga tidak hanya untuk penerangan saja, tetapi juga untuk memasak, pemanas air, pendingin suhu udara, dan aplikasi alat elektronik lainnya (Saepudin, 2018).

Listrik sebagai salah satu bentuk energi final modern memegang peranan penting dalam sejarah perkembangan manusia. Listrik telah membawa banyak perubahan dalam kehidupan manusia sejak pertama kali ditemukan. Pertumbuhan penggunaan listrik sering kali berkorelasi dengan peningkatan kualitas hidup; meningkatkan kesejahteraan individu yang menyebabkan perubahan gaya hidup. Karenanya, tren gaya hidup yang dicirikan dengan penggunaan alat-alat modern semakin meningkatkan ketergantungan masyarakat terhadap pasokan listrik.Kedepannya, listrikakan menjadi bentuk energi akhir yang paling banyak dikonsumsi masyarakat. Beberapa orang bahkan berpendapat bahwa manusia modern tidak dapat bertahan hidup tanpa listrik (Wijaya \& Tezuka, 2013).

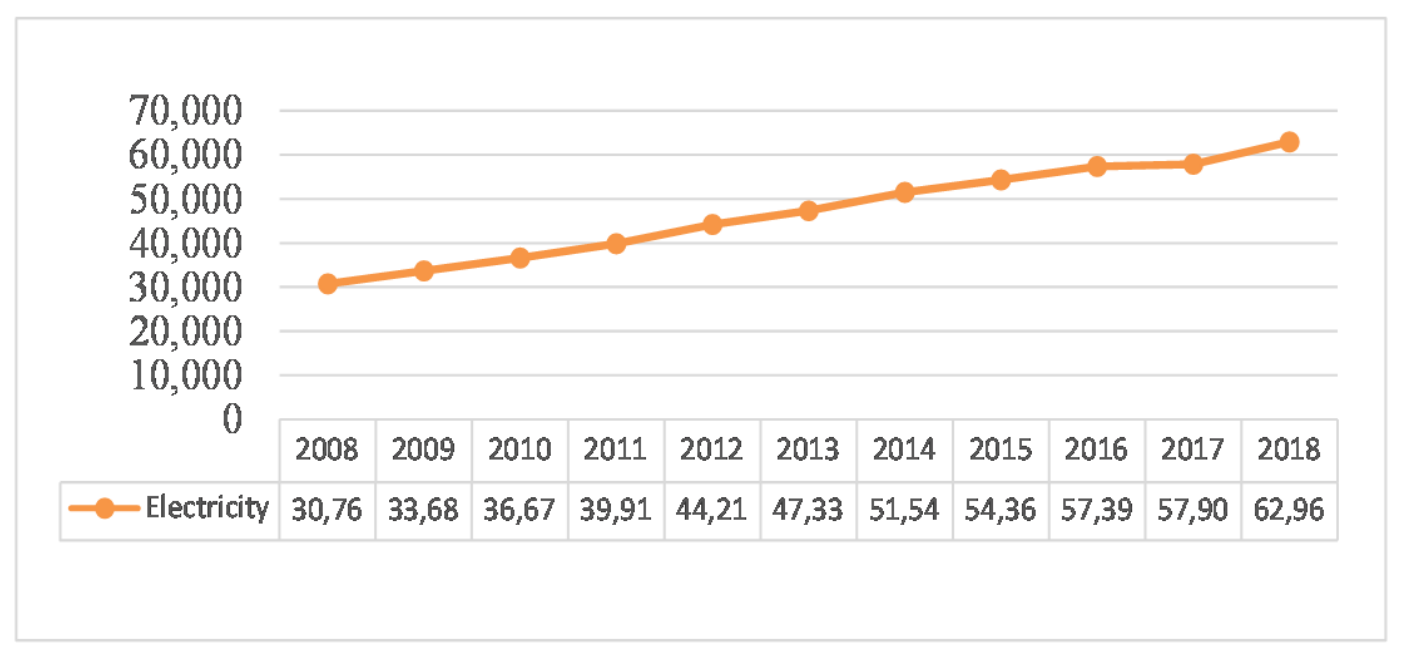

Sumber: KESDM (2019a)

Gambar 1. Konsumsi Listrik Sektor Rumah Tangga, 2008 - 2018 (Ribu BOE)

Gambar 1. menunjukkan banyaknya konsumsi listrik sektor rumah tangga di Indonesia pada tahun 2008-2018. Konsumsi listrik sektor rumah tangga di Indonesia menunjukkan tren peningkatan tiap tahunnya. Pada tahun 2008, konsumsi listrik sektor rumah tangga sebesar 30.764 ribu BOE (Barrel of Oil Equivalent) terus meningkat hingga mencapai 62.963 ribu BOE pada tahun 2018. Konsumsi listrik sektor rumah tangga di Indonesia pada tahun 2018 meningkat sekitar 2 kali lipat dalam kurun waktu 10 tahun sejak tahun 2008. Peningkatan konsumsi listrik pada sektor rumah tangga juga sejalan dengan rasio elektrifikasi Indonesia. Rasio elektrifikasi Indonesia pada tahun 2018 tercatat sebesar 98,86 persen, meningkat dari tahun sebelumnya sebesar 95,35 persen (KESDM, 2019b).

Salah satu komponen penting dalam menjaga keberlangsungan energi adalah melakukan estimasi permintaan energi sebagai dasar perencanaan penyediaan pasoka energi (Azmi \& Amir, 2014). Analisis mengenai permintaan energi erat kaitannya dengan harga dan pendapatan, terutama mengenai elastisitas harga dan elastisitas pendapatan permintaan.Pengetahuan tentang elastisitas tersebut memberikan pertimbangan kepada pembuat kebijakan sejauh mana harga harus naik untuk mengurangi konsumsi internal (Lee \& 
Lee, 2010). Selain itu, keputusan yang valid tentang elastisitas harga dan pendapatan sangat penting untuk estimasi konsumsi listrik rumah tangga di masa mendatang (Pereira Uhr et al., 2019).Beberapa peneliti menegaskan pendapatan sebagai penentu utama dalam permintaan energi rumah tangga (Nazer \& Handra, 2016; Zou \& Luo, 2019). Selain itu, kajian tentang permintaan energi rumah tangga juga selalu mempertimbangkan karakteristik sosial-demografi rumah tangga, seperti tingkat pendidikan, umur, ukuran rumah tangga (Brounen\& Quigley, 2012; Rohut et al., 2015; Estiri 2015; Huebner et al. 2015; Nazer \& Handra, 2016; Salari \& Javid, 2017; Zou \& Luo, 2019; Adusah-Poku \& Takeuchi, 2019) dan juga karakteristik wilayah tempat tinggal (Adusah-Poku \& Takeuchi, 2019).

\section{KAJIAN PUSTAKA}

\section{Teori Permintaan}

Permintaan adalah keinginan konsumen membeli suatu barang pada berbagai tingkat harga selama periode tertentu. Teori permintaan menerangkan tentang ciri hubungan antara jumlah permintaan dan harga. Dalam menganalisa permintaan perlu dibedakan antara permintaan dan jumlah barang yang diminta. Permintaan menggambarkan keadaan keseluruhan hubungan antara harga dan jumlah permintaan. Sedangkan jumlah barang yang diminta merupakan banyaknya permintaan pada tingkat harga tertentu. Hubungan antara jumlah permintaan dan harga ini menimbulkan adanyanya hukum permintaan. Hukum permintaan pada hakekatnya merupakan suatu hipotesis yang menyatakan bahwa semakin rendah harga suatu barang maka semakin banyak permintaan atas barang tersebut, begitupun sebaliknya.

Untuk barang normal, pada harga yang sama bertambahnya pendapatan konsumen dan meratanya pendapatan bisa menyebabkan meningkatnya permintaan. Dengan demikian, kurva permintaan barang yang arahnya negatif ini akan bergeser ke kanan, dengan syarat ceteris paribus. Sebaliknya untuk barang inferior, bertambahnya pendapatan justru mengakibatkan berkurangnya permintaan. Ini berarti dengan naiknya pendapatan, kuva permintaan akan bergeser ke kiri, ceteris paribus. Untuk barang netral, bertambah atau berkurangnya pendapatan tidak akan mempengaruhi fungsi permintaan. Barang-barang normal, seperti kacang kedelai, pakaian, dan sebagainya, selalu mengikuti hukum permintaan yang menyatakan bahwa makin tinggi harga, makin berkurang permintaan, atau sebaliknya. Sedangkan pada barang netral, seperti garam, tinggi rendahnya harga tidak akan (sedikit sekali) mempengaruhi fluktuasi. Sebab, walaupun harga garam turun, orang tidak akan menambah konsumsi garam. Begitu juga sebaliknya bila harga garam naik, konsumen tidak bisa mengurangi kebutuhannya akan garam, kecuali bagi konsumen yang mengalami penyakit tertentu. (Daniel, M., 2001)

\section{Elastisitas Permintaan : Elastisitas Harga dan Pendapatan Elastisitas Harga Permintaan}

Elastisitas harga permintaan adalah ukuran perubahan kuantitas yang diminta atau suatu produk yang dibeli sehubungan dengan perubahan harganya.Elastisitas harga permintaan mengukur kepekaan permintaan setelah adanya perubahan harga produk itu sendiri.

Elastisitas harga permintaan dapat digambarkan melalui rumus:

$$
E_{p}=(\% \Delta Q) /(\% \Delta P)
$$

di mana $\% \Delta Q$ berarti "persentase perubahan dalam jumlah yang diminta" dan $\% \Delta P$ berarti "persentase perubahan harga." Atau elastisitas harga permintaan dapat juga dituliskan dalam persamaan:

$$
E_{p}=\frac{\Delta Q / Q}{\Delta P / P}=\frac{P \Delta Q}{Q \Delta P}
$$


Elastisitas harga biasanya bertanda negatif yang menggambarkan turunnya permintaan ketika adanya kenaikan harga. Nilai dari hasil perhitungan elastisitas disebut dengan koefisien. Koefisien elastitas digunakan untuk melihat seberapa elastis permintaan suatu barang terhadap perubahan harga barang itu. Case et al. (2012) menyebutkan ada 5 jenis elastistitas harga permintaan berdasarkan nilai koefisiennya.

a. Jika koefisien elastisitas harga permintaan bernilai $0(E p=0)$, maka permintaan barang tersebut tergolong inelastis sempurna (perfectly inelastic demand). Tidak ada perubahan permintaan yang terjadi ketika adanya perubahan harga. Kurva permintaan pada barang inelastis sempurna akan berbentuk vertikal.

b. Jika koefisien elastisitas harga permintaan benilai di antara 0 dan $1(0<E p<1)$, maka permintaan barang tersebut inelastis (inelastic demand).

c. Jika koefisien elastisitas harga permintaan bernilai -1 $(E p=-1)$ disebut dengan unit elastis (unitary elastic demand), perubahan $1 \%$ pada harga akan mengakibatkan besarnya perubahan yang sama pada permintaan yakni sebesar $1 \%$ juga.

d. Jika koefisien elastisitas harga permintaan benilai antara 0 dan $-1(-1<E p<0)$ disebut elastis (elastic demand). Artinya, ketika terjadi kenaikan harga maka akan mengakibatkan penurunan permintaan pada barang tersebut.

e. Jika koefisien elastisitas harga permintaan bernilai $\infty($ Ep $>\infty)$ disebut elastis sempurna (perfectly elastic demand), di mana kenaikan harga sekecil apa pun akan mengurangi kuantitas yang diminta menjadi nol. Kurva permintaan yang elastastis sempurna akan berbentuk horizontal.

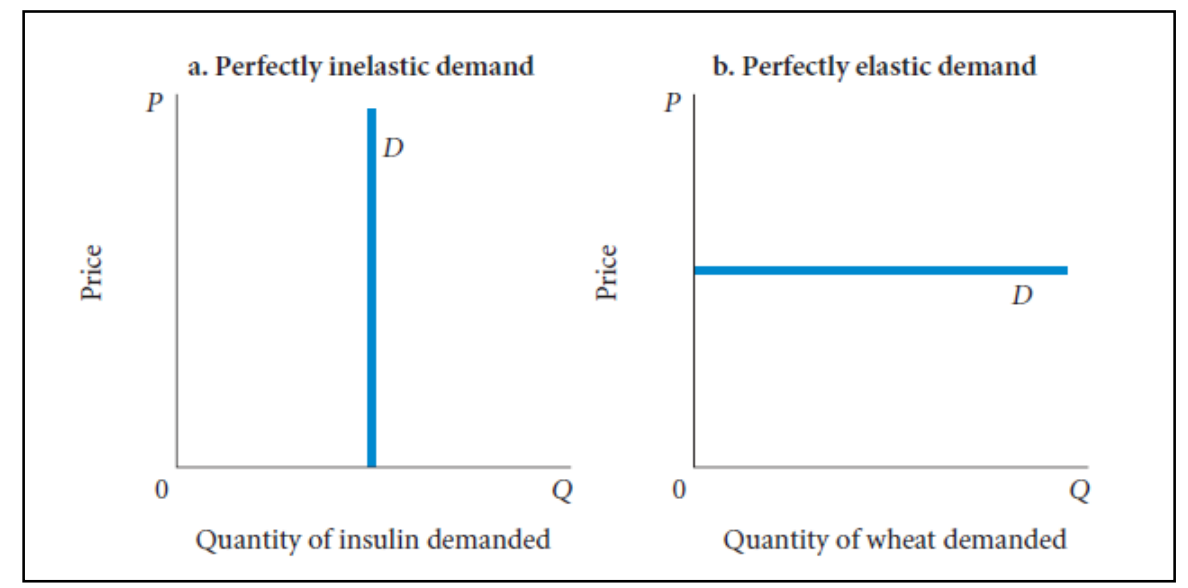

Gambar 2. Kurva Permintaan Inelastis Sempurna dan Elastis Sempurna Sumber: Case et al. (2012:99)

\section{Elastisitas Pendapatan Permintaan}

Elastisitas pendapatan permintaan adalah persentase perubahan dalam kuantitas permintaan, $Q$, yang diakibatkan dari peningkatan 1 persen pendapatan $I$ :

$$
E_{I}=\frac{\Delta Q / Q}{\Delta I / I}=\frac{I}{Q} \frac{\Delta Q}{\Delta I}
$$

a. Jika hasilnya negatif atau $E i<0$ maka penurunan permintaan barang bisa saja diakibatkan karena peningkatan pendapatan. Hal ini bisa terjadi pada barang-barang inferior.

b. Jika hasilnya positif atau $0<E i<1$ maka peningkatan pendapatan dapat dikatakan bisa meningkatkan permintaan suatu barang. Hasil ini berlaku elastisitas pendapatan barang normal atau barang-barang sehari yang merupakan kebutuhan pokok seseorang. 
c. Jika hasilnya lebih besar dari 1 atau $E i>1$ maka peningkatan pendapatan bisa mengakibatkan permintaan barang superior atau merah juga meningkat.

d. Jika hasilnya sama dengan 0 atau $E i=0$ maka artinya tidak adanya perubahan permintaan barang meskipun terjadi peningkatan pendapatan

Elastisitas pendapatan dari permintaan suatu produk bisa dikatakan elastis atau tidak elastis berdasarkan kategorinya — apakah itu barang inferior atau barang normal.Jika koefisien elastisitaspendapatan permintaan lebih dari nol, produk tersebut elastis terhadap pendapatan. Barang normal memiliki koefisien elastisitaspendapatanpermintaan positif. Artinya, permintaan akan barang tersebut akan meningkat seiring dengan meningkatnya pendapatan.

Namun, barang normal dapat dipecah menjadi kebutuhan normal dan kemewahan normal. Kebutuhan normal memiliki koefisien elastisitas pendapatan permintaan yang positif tetapi rendah dibandingkan dengan barang mewah.Koefisien elastisitas pendapatan permintaan untuk kebutuhan normal adalah antara 0 dan 1 . Kebutuhan normal meliputi kebutuhan pokok seperti susu, bahan bakar, atau obat-obatan.

Faktor-faktor seperti perubahan harga atau perubahan pendapatan konsumen tidak mempengaruhi permintaan barang yang diperlukan. Persentase perubahan permintaan produk lebih kecil sebanding dengan persentase perubahan pendapatan konsumen.Kemewahan, di sisi lain, sangat elastis terhadap pendapatan. Contoh barang mewah termasuk elektronik atau perhiasan kelas atas. Misalnya, jika pendapatan konsumen meningkat, konsumen dapat berinvestasi atau membeli ponsel canggih atas atau televisi HD. Persentase perubahan permintaan lebih sebanding dengan perubahan pendapatan. Namun, perlu diperhatikan bahwa konsep kemewahan itu kontekstual dan bergantung pada keadaan konsumen.

Barang inferior memiliki elastisitas pendapatan permintaan yang negatif, yaitu koefisien elastisitas pendapatan permintaan kurang dari 0. Jika pendapatan konsumen meningkat, permintaanakan lebih sedikit. Barang inferior disebut inferior karena biasanya memiliki alternatif yang lebih unggul.Biasanya, ketika pertumbuhan ekonomi membaik dan adanya peningkatan pendapatan konsumen, permintaan akan barang-barang berkualitas rendah berkurang dan terjadi ayunan ke dalam pada kurva permintaan.Akibatnya, ketika pendapatan berkurang dan harga barang meningkat karena resesi, maka permintaan barang inferior meningkat, sehingga menyebabkan ayunan keluar dari kurva permintaan.

\section{Listrik}

Listrik sampai ke konsumen melalui sistem penyaluran energi listrik yang terbagi menjadi beberapa tahap yang disebut dengan Sistem Tenaga Listrik. Tahapan pada Sistem Tenaga Listrik adalah pembangkitan, transmisi, dan distribusi (Doloksaribu, 2010). Penyediaan listrik di Indonesia dikelola oleh PT. Perusahaan Listrik Negara (PLN).Sebagai pemegang hak tunggal penyediaan energi listrik untuk masyarakat, PLN membagi konsumen listrik ke dalam berbagai kelompok (Romadhoni \& Akmad, 2020). Menurut kegiatan ekonomi, konsumen dibagi menjadi empat kelompok, yaitu: (1) bisnis, (2) industri, (3) publik atau pemerintah, dan (4) rumah tangga (PLN, 2017). Konsumen sektor rumah tangga dikelompokkan menjadi enam jenis berdasarkan kategori tarif listrik dan batas daya listrik: 450 watt,900 watt, 1300 watt, 2200 watt, 2201 - 6600 watt, dan> 6600 watt (Nababan, 2015). Daya listrik 450 watt dan daya 900 watt merupakan daya listrik yang diperuntukkan subsidi.

Tarif listrik oleh PLN diatur dalam Peraturan Menteri ESDM No.31 Tahun 2014 dan No. 9 Tahun 2015. Tarif listrik untuk rumah tangga dapat dilihat pada Tabel 1. Tarif listrik terdiri atas tarif listrik reguler dan tarif listrik prabayar. Tarif listrik regular dibayar setelah pemakaian sedangkan tarif listrik prabayar dibayarkan sebelum pemakaian listrik oleh konsumen. Tarif listrik untuk keperluan rumah tangga, terdiri atas:

1. Golongan tarif untuk keperluan rumah tangga kecil pada tegangan rendah, dengan daya sampai dengan 450 VA, $900 \mathrm{VA}, 1.300 \mathrm{VA}$, dan 2.200 VA (R-1/TR); 
2. Golongan tarif untuk keperluan rumah tangga menengah pada tegangan rendah, dengan daya 3.500 VA sampai dengan 5.500 VA (R-2/TR); dan

3. Golongan tarif untuk keperluan rumah tangga besar pada tegangan rendah, dengan daya 6.600 VA ke atas (R-3/TR).

Tabel 1.

Tarif Listrik Untuk Keperluan Rumah Tangga

\begin{tabular}{|c|c|c|c|c|c|c|}
\hline \multirow[b]{2}{*}{ No } & \multirow[b]{2}{*}{$\begin{array}{l}\text { Golongan } \\
\text { Tarif }\end{array}$} & \multirow[b]{2}{*}{ Batas Daya } & \multicolumn{3}{|c|}{ Reguler } & \multirow[b]{2}{*}{$\begin{array}{l}\text { Prabayar } \\
(\mathrm{Rp} / \mathrm{kWh})\end{array}$} \\
\hline & & & $\begin{array}{c}\text { Biaya } \\
\text { Beban } \\
\text { (Rp/kVA } \\
\text { /bulan) } \\
\end{array}$ & $\begin{array}{c}\text { Biaya Pemakaian } \\
\text { (Rp/kWh) }\end{array}$ & & \\
\hline 1. & R-1/TR & s.d. $450 \mathrm{VA}$ & 11.000 & 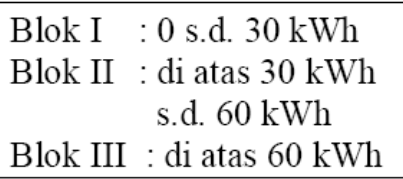 & $\begin{array}{l}: 169 \\
: 360 \\
: 495 \\
\end{array}$ & 415 \\
\hline 2. & R-1/TR & $900 \mathrm{VA}$ & 20.000 & 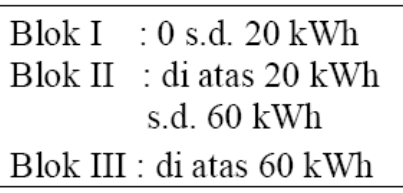 & $\begin{array}{l}: 169 \\
: 360 \\
: 495\end{array}$ & 605 \\
\hline 3. & R-1/TR & $1.300 \mathrm{VA}$ & $*)$ & 1.352 & & 1.352 \\
\hline 4. & R-1/TR & $2.200 \mathrm{VA}$ & $*)$ & 1.352 & & 1.352 \\
\hline 5. & $\mathrm{R}-2 / \mathrm{TR}$ & $\begin{array}{l}3.500 \mathrm{s.d} . \\
5.500 \mathrm{VA}\end{array}$ & $*)$ & 1.352 & & 1.352 \\
\hline 6. & R-3/TR & $\begin{array}{l}6.600 \mathrm{VA} \\
\mathrm{Ke} \text { atas }\end{array}$ & *) & 1.352 & & 1.352 \\
\hline
\end{tabular}

Catatan :

*) Diterapkan Rekening Minimum (RM):

$\mathrm{RM1}=40$ (Jam Nyala) $\mathrm{x}$ Daya Tersambung $(\mathrm{kVa}) \times$ Biaya Pemakaian

Penelitian-penelitian sebelumnya mengenai elastisitas harga dan elastisitas pendapatan pada permintaan listrik rumah tangga menunjukkan tanda koefisien yang seragam. Elastisitas harga permintaan listrik pada penelitian sebelumnya bertanda negatif dan berkisar antara 0 sampai 1 , yang menunjukkan harga permintaan listrik bersifat elastis (elastic-demand). Sedangkan pada elastistas pendapatan permintaan bernilai positif antara 0 dan 1 , yang menunjukkan permintaan listrik elastis terhadap pendapatan (income-elastic).

Pereira Uhr et al. (2019) menganalisis elastisitas harga dan elastisitas pendapatan pada permintaan listrik rumah tangga di Brazil dengan menggunakan Quantile Regression. Data yang digunakan adalah data 2 periode, yaitu periode tahun 1998-1999 dan periode tahun 20082013. Hasil penelitiannya menunjukkan elastisitas harga permintaan listrik berkisar dari $-0,46$ hingga $-0,56$, dan elastisitas pendapatan permintaan listrik berkisar dari 0,20 hingga 0,32 masing-masing.

Romero-Jordánet al. (2014) menganalisis determinan permintaan listrik rumah tangga di Spanyol dengan data panel antara tahun 1998 dan 2009. Hasil penelitianya menunjukkan elastisitas harga pada jangka pendek dan jangka panjang masing-masing sebesar -0,26 dan 0,37 . Sedangkan elastisitas pendapatan adalah 0,31 (jangka pendek) dan 0,43 (jangka panjang).

Cao et al. (2016) mengestimasi elastisitas pendapatan dan elastisitas harga untuk berbagai jenis energi dengan menggunakan data mikro rumah tangga perkotaan Cina yang dikumpulkan oleh National berau of Statisticspada tahun 2002-2009. Penelitaiannya menerapkan model dua tahap Almost Ideal Demand System (AIDS). Hasil penelitiannya menunjukkan estimasi elastisitas harga listrik berkisar antara -0,49 sampai dengan -0,57. 
Ngui et al. (2011) mengestimasi elastisitas harga permintaan berbagai jenis bahan bakar dengan mengaplikasikan Linear Approximate Almost Ideal Demand System (LA-AIDS) pada 3.665 rumah tangga sampel di Kenya pada tahun 2009. Hasil penelitiannya menunjukkan elastisitas harga permintaan listrik adalah inelastis (price inelastic). Elastisitas pendapatan permintaan listrik adalah inelastis (income inelastic).

Saha \& Bhattacharya (2018) mengestimasi elastisitas harga dan pendapatan permintaan listrik di Bengal Barat, India. Penelitiannya membagi konsumen menjadi empat kategori, yaitu pertanian, perdagangan, industri, dan domestik. Analisis yang digunakan adalah analisis data panel yang mencakup 15 tahun untuk empat kategori konsumen. Hasil penelitiannya menunjukkan elastisitas harga permintaan listrik bernilai negatif pada semua sektor. Elastisitas pendapatan permintaan listrik bernilai positif pada semua sektor.

\section{Framework Penelitian}

Model dalam penelitian ini ditunjukkan dalam persamaan matematis dibawah ini.

1. Model Permintaan Listrik

$$
\begin{aligned}
& \text { LnLISTRIK }_{i}=\beta_{0}+\beta_{1} \text { LnHARGALISTRIK }_{i}+\beta_{2} \text { LnINCOME }_{i}+\beta_{3} \text { SIZE }_{i}+\beta_{4} \text { AGE }_{i} \\
& +\beta_{5} A G E_{i}^{2}+\beta_{6} E D U 1_{i}+\beta_{7} E D U 2_{i}+\beta_{8} Z O N E_{i}+\mu_{i}
\end{aligned}
$$

Dimana:

(4)

$\begin{array}{ll}\text { LnLISTRIK } & : \text { logaritma natural konsumsi listrik oleh rumah tangga } \\ \text { LnHARGALISTRIK } & : \text { logaritma natural harga listrik } \\ \text { LnINCOME } & : \text { logaritma natural pendapatan per kapita rumah tangga } \\ \text { SIZE } & : \text { ukuran rumah tangga } \\ \text { AGE } & : \text { umur kepala rumah tangga } \\ \text { AGE } & : \text { nilai kuadrat dari umur } \\ \text { EDU1 } & : \text { dummy pendidikan dasar dan menengah krt } \\ \text { EDU2 } & : \text { dummy pendidikan tinggi krt } \\ \text { ZONE } & : \text { intersep } \\ \beta_{0} & : \text { parameter } \\ \beta_{0}, \beta_{1}, \ldots, \beta_{10} & : \text { error term } \\ \mu & : \text { rumah tangga } \\ i & \text { argatinggal di perkotaan }\end{array}$

2. Model Elastisitas Harga dan Elastisitas Pendapatan Permintaan Listrik

$$
\begin{aligned}
& \eta_{\text {plistrik }}=\frac{d(\text { LnLISTRIK })}{d(\text { LnHARGALISTRIK })}=\beta_{1} \\
& \eta_{\text {lilistrik }}=\frac{d(\text { LnLISTRIK })}{d(\text { LnINCOME })}=\beta_{2}
\end{aligned}
$$

Keterangan:

$\begin{array}{ll}\eta_{\text {plistrik }} & \text { : elastisitas harga permintaan listrik } \\ \eta_{\text {lilistrik }} & \text { : elastisitas pendapatan permintaan listrik } \\ \beta_{1} & \text { : intersep variabel LnListrik pada model permintaan listrik } \\ \beta_{2} & \text { : intersep variabel LnIncomepada model permintaan listrik }\end{array}$

\section{METODE PENELITIAN}

Penelitian ini dilakukan secara kuantitatif. Metode yang digunakan adalah regresi linear berganda dengan pendekatan Ordinary Least Squares. OLS digunakan dalam penelitian ini 
untuk melihat pengaruh harga listrik, pendapatan per kapita rumah tangga, umur kepala rumah tangga, tingkat pendidikan kepala rumah tangga, ukuran rumah tangga, dan wilayah tempat tinggal terhadap permintaan energi listrik pada sektor rumah tangga di Indonesia. OLS juga digunakan untuk mengestimasi elastisitas harga dan elastisitas pendapatan pada permintaan listrik di Indonesia. Variabel yang digunakan dalam penelitian ini merujuk pada Susenas Maret 2018. Oleh karena itu, definisi operasional yang dipakai dalam penelitian ini mengacu pada buku Konsep dan Definisi Susenas Maret 2018 yang menjadi pedoman dalam pengumpulan data di lapangan oleh BPS (2019b).

Penelitian ini menggunakan data mikro Susenas Maret 2018 dengan jumlah sampel total sebanyak 300.000 rumah tangga sampel. Jumlah rumah tangga sampel yang berhasil didata adalah sebanyak 295.155 rumah tangga, kemudian dilakukan filtering untuk mendapatkan rumah tangga yang menggunakan listrik. Rumah tangga yang menggunakan listrik adalah sebanyak 282.272 rumah tangga. Setelah unit analisis diperoleh, masing-masing model dibentuk untuk mengestimasi permintaan rumah tangga pengguna listrik.

Tabel 2. Definisi Operasional Variabel Penelitian

\begin{tabular}{|c|c|c|}
\hline Nama Variabel & Notasi & Pengukuran \\
\hline \multicolumn{3}{|l|}{ Variabel Terikat } \\
\hline Konsumsi Listrik & LnLISTRIK & $\begin{array}{l}\text { banyaknya konsumsi listrik oleh rumah tangga } \\
\text { dalam sebulan }(\mathrm{kWh})\end{array}$ \\
\hline \multicolumn{3}{|l|}{ Variabel Bebas } \\
\hline Harga Listrik & LnHARGALISTRIK & $\begin{array}{l}\text { Pengeluatan listrik dalam sebulan dibagi } \\
\text { jumlah pemakaian listrik dalam sebulan } \\
(\mathrm{Rp} / \mathrm{kWh})\end{array}$ \\
\hline Pendapatan per Kapita & LnINCOME & $\begin{array}{l}\text { Pendekatan pengeluaran per kapita rumah } \\
\text { tangga }\end{array}$ \\
\hline Ukuran Rumah Tangga & SIZE & Jumlah anggota rumah tangga (orang) \\
\hline Umur & $A G E, A G E^{2}$ & $\begin{array}{l}\text { Umur kepala rumah tangga (tahun). } \\
A G E^{2} \text { adalah umur yang dikuadratkan }\end{array}$ \\
\hline \multirow[t]{2}{*}{ Tingkat Pendidikan } & $E D U 1$ & $\begin{array}{l}1=\text { pendidikan dasar dan menengah } \\
0=\text { lainnya }\end{array}$ \\
\hline & $E D U 2$ & $\begin{array}{l}1=\text { pendidikan tinggi } \\
0=\text { lainnya }\end{array}$ \\
\hline Wilayah Tempat Tinggal & ZONE & $\begin{array}{l}1=\text { perkotaan } \\
0=\text { perdesaan }\end{array}$ \\
\hline
\end{tabular}

\section{HASIL DAN PEMBAHASAN}

\section{Gambaran Umum Objek Penelitian}

Gambaran umum objek penelitian tersaji pada Tabel 3. Rata-rata usia kepala rumah tangga di Indonesia adalah 48,504 tahun. Mayoritas kepala rumah tangga telah mengenyam pendidikan dasar dan menengah yaitu sebesar 67,4 persen sedangkan kepala rumah tangga yang telah menempuh pendidikan tinggi sebesar 8,1 persen. Namun, kepala rumah tangga yang tidak memiliki ijazah masih ditemukan sebanyak 24,5 persen. Tanpa berbekal ijazah dari pendidikan formal, kepala rumah tangga akan sulit untuk mencari pekerjaan pada sektor formal sehingga mereka beralih ke sektor informal. Sektor informal identik dengan gajinya yang sedikit, resiko tinggi dalam pekerjaan dan tidak memiliki jaminan kerja yang layak (ILO, 2010).

Mayoritas rumah tangga di Indonesia beranggotakan sebanyak $3-4$ orang. Hal ini menggambarkan ukuran rumah tangga di Indonesia sudah mengikuti anjuran jumlah rumah tangga ideal oleh pemerintah. Rumah tangga idealnya beranggotakan 4 orang (Ramadhani \& Munandar, 2017). Sebanyak 42,9 persen rumah tangga tinggal di wilayah perkotaan dan 57,1 persen rumah tangga tinggal di wilayah perdesaan. 
Tabel 3.Gambaran Umum Objek Penelitian

\begin{tabular}{|l|r|r|r|r|r|}
\hline Variabel & Obs & Mean & Std.Dev. & Min & Max \\
\hline LnHARGALISTRIK & 282.272 & 6,673 & 0,579 & 2,939 & 11,462 \\
\hline LnINCOME & 295.155 & 13,732 & 0,665 & 11,33 & 17,944 \\
\hline AGE & 295.155 & 48,504 & 13,508 & 11 & 97 \\
\hline AGE & 295.155 & $2.535,081$ & $1.388,888$ & 121 & 9.409 \\
\hline $\begin{array}{l}\text { EDU1 } \\
\text { (pendidikan dasar dan } \\
\text { menengah=1) }\end{array}$ & 295.155 & 0,674 & 0,469 & 0 & 1 \\
\hline $\begin{array}{l}\text { EDU2 } \\
\text { (pendidikan tinggi=1) }\end{array}$ & & & & & \\
\hline SIZE & 295.155 & 0,081 & 0,273 & 0 & \\
\hline ZONE & 295.155 & 3,835 & 1,730 & & 1 \\
\hline
\end{tabular}

\section{Hasil Estimasi Model Ordinary Least Square}

Hasil estimasi permintaaan listrik dengan model OLS dapat dilihat melalui Tabel 4. Uji parsial dengan uji $t$ menunjukkan bahwa masing-masing variabel bebas yang digunakan dalam model signifikan pada level $\alpha=1 \%$ baik pada model permintaan listrik. Hasil uji serentak dengan uji $F$ juga menunjukkan hasil yang signifikan pada level $\alpha=1 \%$ yang artinya semua variabel bebas yang digunakan secara simultan mempunyai pengaruh yang signifikan pada permintaan listrik Pada model permintaan listrik, nilai $R$-squared sebesar 0,393 yang artinya permintaan listrik oleh rumah tangga di Indonesia 39,7 persen dipengaruhi oleh variabel harga listrik, pendapatan per kapita rumah tangga, ukuran rumah tangga, umur kepala rumah tangga, tingkat pendidikan kepala rumah tangga, dan wilayah tempat tinggal, sedangkan sisanya 60,3 persen dipengaruhi oleh variabel lain di luar model. Kecilnya nilai $R$-squared pada estimasi model permintaan listrik juga disebabkan karena heterogenitas data cross section yang digunakan pada penelitian ini.

Tabel 4. Hasil Estimasi Permintaan Listrik dan LPG dengan Model OLS

\begin{tabular}{|l|c|}
\hline & $\begin{array}{c}\text { Koefisien } \\
\text { VARIABLES }\end{array}$ \\
\hline & $\begin{array}{c}\text { Ltandard Error) } \\
\text { Listrik }\end{array}$ \\
\hline LnHARGALISTRIK & $-0.550^{* * *}$ \\
\hline LnINCOME & $(0.00260)$ \\
\hline & $0.794^{* * *}$ \\
\hline SIZE & $(0.00258)$ \\
\hline AGE & $0.164^{* * *}$ \\
\hline EDU1 & $(0.000866)$ \\
\hline EDU2 & $0.0295^{* * *}$ \\
\hline & $(0.000605)$ \\
\hline ZONE & $-0.000246^{* * *}$ \\
\hline Constant & $(5.91 \mathrm{e}-06)$ \\
\hline & $0.175^{* * *}$ \\
\hline Observations & $(0.00348)$ \\
\hline$R$-squared & $0.381^{* * *}$ \\
\hline Prob $>$ F & $(0.00600)$ \\
\hline
\end{tabular}


Tabel 4 menampilkan hasil pengujian model terhadap asumsi klasik pada regresi OLS untuk model permintaan listrik. Berdasarkan hasil uji normalitas Jarque-Bera, asumsi residual berdistribusi normal tidak terbukti secara signifikan karena nilai $p$-value $<\alpha 5 \%$ sehingga $H_{0}$ ditolak. Pengujian multikolinieritas melalui Varian Inflation Factor (VIF) menunjukkan nilai kurang dari 10 untuk masing-masing variabel kecuali pada variabel $A G E$ dan $A G E^{2}$.

Tabel 5.Uji Asumsi Klasik

\begin{tabular}{|c|c|c|}
\hline No & Asumsi & Model Permintaan Listrik \\
\hline 1. & Normalitas & Jerque-Bera $p=0,000$ \\
\hline 2. & Multikolineritas & $\begin{array}{l}\quad \text { Varian Inflation Factor (VIF) } \\
\text { LnHARGALISTRIK=1,27 } \\
\text { LnINCOME }=1,64 \\
\text { SIZE }=1,23 \\
A G E=37,23 \\
A G E^{2}=37,67 \\
E D U 1=1,46 \\
E D U 2=1,54 \\
\text { ZONE }=1,11\end{array}$ \\
\hline 3. & Heteroskedastisitas & $\begin{array}{c}\text { Breusch-Pagan/Cook-Weisberg heteroscedasticity test } \\
\text { p-value } 0.000\end{array}$ \\
\hline 4. & Autokolinieritas & Tidak dilakukan pada data cross section \\
\hline
\end{tabular}

Keterangan: *signifikan pada $\alpha=10 \%, * *$ signifikan pada $\alpha=5 \%, * * *$ signifikan pada $\alpha=1 \%$

Uji heteroskedastisitas dilakukan untuk menilai apakah ada varian dari residual untuk semua pengamatan yang tidak konstan pada model regresi linear. Uji asumsi heteroskedastisitas residualmenggunakan uji Breusch-Paganyang menampilkan nilai $p$-value kurang dari $\alpha=5 \%$ (gagal tolak $\mathrm{H}_{0}$ ). Penelitian ini menggunakan data cross section sehingga uji autokolinieritas tidak dilakukan. Hasil uji asumsi klasik di atas dapat disimpulkan uji asumsi klasik dalam OLS tidak terpenuhi baik pada model permintaan listrik. Untuk mengatasi adanya pelanggaran asumsi tersebut dilakukan regresi dengan Robust Standard Error. Hasil estimasi OLS dengan Robust Standard Error dapat dilihat melalui Tabel 4.7.

Tabel 6. Hasil Estimasi Permintaan Listrik dengan Robust Standard Error

\begin{tabular}{|l|c|}
\hline & Koefisien \\
\hline VARIABLES & (Standard Error) \\
\hline LnHARGALISTRIK & Listrik \\
\hline LnINCOME & $-0.550^{* * *}$ \\
\hline \multirow{2}{*}{ SIZE } & $(0.00302)$ \\
\hline & $0.794^{* * *}$ \\
\hline AGE & $(0.00283)$ \\
\hline & $0.164^{* * *}$ \\
\hline & $(0.000993)$ \\
\hline EDU ${ }^{2}$ & $0.0295^{* * *}$ \\
\hline & $(0.000652)$ \\
\hline EDU2 & $-0.000246^{* * *}$ \\
\hline & $(6.30 \mathrm{e}-06)$ \\
\hline ZONE & $0.175^{* * *}$ \\
\hline & $(0.00357)$ \\
\hline Constant & $0.381^{* * *}$ \\
\hline & $(0.00601)$ \\
\hline Observations & $0.329^{* * *}$ \\
\hline$R$-squared & $(0.00281)$ \\
\hline Prob $>$ F & $-4.536^{* * *}$ \\
\hline Keterangan: & $(0.0366)$ \\
\hline
\end{tabular}

Keterangan: *signifikan pada $\alpha=10 \%, * *$ signifikan pada $\alpha=5 \%$, ${ }^{* * *}$ signifikan pada $\alpha=1 \%$ 
Model estimasi permintaan listrik rumah tangga di Indonesia dengan Robust Standard Error:

LnLTSTRIK $_{a}=-4,536-0,550$ LnHARGALISTRIK $_{i}+0,794$ LnINCOME $_{i}$

$$
\begin{array}{r}
+0,164 S I Z E_{i}+0,030 A G E_{i}-0,000 A G E_{i}^{2}+0,175 E D U 1_{i} \\
+0,381 E D U 2_{i}+0,329 Z_{2 O N E_{i} \ldots \ldots \ldots \ldots \ldots \ldots \ldots \ldots \ldots}
\end{array}
$$

a. Harga listrik berpengaruh negatif dan signifikan terhadap permintaan listrik. Ketika terjadi kenaikan harga listrik sebesar 1 persen maka permintaan listrik akan mengalami penururan sebesar 0,550 persen, dengan asumsi variabel lain tetap.

b. Pendapatan per kapita rumah tangga berpengaruh positif dan signifikan. Ketika terjadi kenaikan harga pendapatan per kapita sebesar 1 persen maka permintaan listrik akan mengalami peningkatan sebesar 0,794 persen, dengan asumsi variabel lain tetap.

c. Ukuran rumah tanga berpengaruh positif dan signifikan terhadap permintaan listrik. Setiap bertambahnya 1 orang dalam rumah tangga akan meningkatkan permintaan listrik sebesar 0,164 persen, dengan asumsi variabel lain tetap.

d. Umur kepala rumah tangga berpengaruh positif dan signifikan terhadap permintaan listrik. Setiap 1 tahun bertambahnya umur kepala rumah tangga akan meningkatkan permintaan listrik sebesar 0,030 persen, dengan asumsi variabel lain tetap. Umur kuadrat bertanda negatif menunjukkan bahwa pada titik tertentu permintaan listrik akan berkurang setiap adanya pertambahan umur.

e. Tingkat pendidikan kepala rumah tangga berpengaruh positif dan signifikan terhadap permintaan listrik rumah tangga. Permintaan listrik olehkepala rumah tangga dengan tingkat pendidikan dasar dan menengah lebih besar 0,175 persen jika dibandingkan dengan kepala rumah tangga yang tidak punya ijazah. Permintaan listrik oleh kepala rumah tangga dengan tingkat pendidikan tinggi lebih besar 0,381 persen jika dibandingkan dengan kepala rumah tangga yang tidak punya ijazah.

f. Wilayah tempat tinggal berpengaruh positif dan signifikan terhadap permintaan listrik rumah tangga. Permintaan listrik oleh rumah tangga perkotaan lebih besar 0,329 persen jika dibandingkan dengan rumah tangga perdesaan.

\section{Elastisitas Harga Permintaan dan Elastisitas Pendapatan Permintaan}

Penelitian ini menggunakan model linear log-log, sehingga nilai elastisitas harga dan elastisitas pendapatan dapat dilihat langsung melalui estimasi persamaan permintaan yang dihasilkan melalui regresi OLS dengan Robust Standard Error. Elastisitas harga dan elastisitas pendapatan pada permintaan listrik dapat dilihat pada Tabel 7. Elastisitas harga digunakan untuk melihat respon dari permintaan terhadap perubahan harga. Elastisitas harga listrik sebesar -0,550, artinya setiap kenaikan harga sebesar 1 persen akan mengakibatkan permintaan listrik turun sebesar 0,550 persen. Koefisien elastisitas bernilai antara 0 dan $-1(-1<E p<0)$. Hal ini mengindikasikan bahwa harga listrik elastis terhadap permintaannya (elastic-demand).

Tabel 7. Elastisitas Harga dan Elastisitas Pendapatan pada Permintan Listrik

\begin{tabular}{|l|l|c|c|}
\hline No & Permintaan & Elastisitas Harga & Elastisitas Pendapatan \\
\hline 1. & Listrik & $-0,550$ & 0,794 \\
\hline
\end{tabular}

Sumber: BPS, 2018

Elastisitas pendapatan digunakan untuk melihat perubahan permintaan yang terjadi akibat perubahan pendapatan. Koefisien elastisitas pendapatan pada permintaan listrik adalah sebesar 0,794 yang artinya ketika terjadi peningkatan pendapatan sebesar 1 persen, permintaan listrik akan meningkat sebesar 0,794 persen. Koefisien elastisitas pendapatan pada permintaan listrik benilai positif yang mengindikasikan listrik adalah income-elastic dan tergolong ke dalam "normal goods" dan merupakan kebutuhan pokok bagi rumah tangga di Indonesia. 


\section{PEMBAHASAN}

Hasil penelitian menunjukkan variabel harga listrik memiliki pengaruh negatif dan signifikan terhadap permintaan listrik rumah tangga. Artinya semakin tinggi listrik maka permintaannya akan menurun, begitu pun sebaliknya. Dengan demikian, hasil penelitian ini tidak bertentangan dengan teori permintaan. Hasil penelitian ini sejalan dengan hasil penelitian oleh Salari \& Javid (2017) dan Adusah-Poku \& Takeuchi (2019).

Hasil penelitian juga menunjukkan variabel pendapatan per kapita yang positif dan signifikan terhadap permintaan listrik. Artinya semakin tinggi pendapatan per kapita rumah tangga maka permintaan terhadap listrikakan meningkat pula. Hasil penelitian ini mendukung penelitian-penelitian sebelumnya yang dilakukan oleh Brounen \& Quigley (2012), Estiri (2015), Nazer \& Handra (2016), Salari \& Javid (2017), dan Zou \& Luo (2019). Pendapatan yang meningkat mengindikasikan kemampuan rumah tangga untuk membeli barang-barang elektronik meningkat sehingga konsumsi listrik pun meningkat (Nazer \& Handra, 2016).

Ukuran rumah tangga memiliki pengaruh positif dan signifikan terhadap pengeluaran listrik rumah tangga. Artinya semakin banyak jumlah anggota dalam rumah tangga maka konsumsi listrik rumah tangga pun semakin meningkat. Semakin tinggi ukuran rumah tangga berarti semakin banyak pula pemakai listrik. Rumah tangga dengan anggota rumah tangga yang lebih banyak cenderung mengonsumsi lebih banyak alat elektronik sehingga dianggap mengonsumsi listrik listrik lebih banyak (Zou \& Luo, 2019).

Hasil penelitian menunjukkan umur kepala rumah tangga memiliki pengaruh positif dan signifikan terhadap permintaan listrik rumah tangga. Sedangkan umur kuadrat menunjukkan pengaruh negatif dan signifikan. Hal ini menandakan semakin bertambahnya umur kepala rumah tanga maka konsumsi listrik pun akan meningkat hingga pada titik tertentu bertambahnya umur kepala rumah tangga maka konsumsi listriknya akan berkurang. Pengaruh umur terhadap permintaan listrik dapat diilustrikan seperti bentuk $\mathrm{U}$ terbalik (inverted $U$ shape).Hasil penelitian ini sejalan dengan penelitian sebelumnya oleh Brounen \& Quigley (2012) dan Nazer \& Handra (2016).

Berbeda dengan hasil penelitian Zou \& Luo (2019), penelitian ini menemukan pendidikan kepala rumah tangga memiliki pengaruh positif dan signifikan terhadap permintaan listrik rumah tangga. Semakin tinggi jenjang pendidikan yang ditempuh oleh kepala rumah tangga. Jenjang pendidikan yang lebih tinggi oleh kepala rumah tangga mengindikasikan pendapatan yang lebih tinggi yang diperoleh oleh kepala rumah tangga sehingga permintaan listrik pun akan semakin meningkat. Kaitan antara pendidikan dan pendapatan dikenal dengan istilah 'retun to education'.

Wilayah tempat tinggal berpengaruh positif dan signifikan terhadap permintaan listrik rumah tangga. Hasil penelitian ini sejalan dengan hasil penelitian oleh Adusah-Poku \& Takeuchi (2019) yang mengatakan bahwa permintaan listrik rumah tangga perkotaan lebih besar jika dibandingkan dengan permintaan listrik rumah tangga perdesaan. Hal ini mengindikasikan rumah tangga perkotaan memiliki daya beli yang lebih tinggi, dan dengan demikian, lebih mungkin untuk membelanjakan listrik. Menurut Mensah \& Adu (2015), rumah tangga yang tinggal di perkotaan akan menghabiskan bahan bakar lebih banyak dibanding dengan rumah tangga yang tinggal di perdesaan.

\section{KESIMPULAN DAN SARAN}

Variabel harga berpengaruh negatif dan signifikan terhadap permintaan listrik, sedangkan variabel pendapatan per kapita, ukuran rumah tangga, umur kepala rumah tangga, pendidikan kepala rumah tangga, dan wilayah tempat tinggal berpengaruh positif dan signifikan terhadap permintaan listrik. 
Koefisien elastisitas harga permintaan listrik menunjukkan hasil yang tergolong elastis (elastic-demand). Artinya, ketika terjadi kenaikan harga pada listrik maka akan menurunkan permintaan terhadap listrik tersebut. Kemudian, jika dilihat dari koefisien elastisitas pendapatan permintaan listrik yang benilai positif dan kurang dari 1 mengindikasikan permintaan listrik adalah elastis terhadap pendapatan per kapita rumah tangga (income-elastic). Hal ini menunjukkan listrik tergolong "normal goods" dan merupakan kebutuhan pokok bagi rumah tangga di Indonesia.

Berdasarkan hasil penelitian, permintaan listrik semakin meningkat seiring dengan meningkatnya pendidikan kepala rumah tangga. Artinya semakin tinggi pendidikan yang ditempuh oleh seseorang tidak menjamin penggunaan listrik yang lebih bijaksana. Oleh karena itu, pemerintah perlu meningkatkan pemahaman masyarakat tentang penghematan energi melalui investasi modal manusia. Hasil penelitian menunjukkan variabel harga memiliki pengaruh negatif dan signifikan terhadap permintaan listrik, sehingga variabel ini dapat dijadikan kontrol oleh pemerintah jika ingin melakukan kebijakan penghematan listrik di kemudian hari.Hasil penelitian menunjukkan bahwa listrik sebagai kebutuhan pokok bagi rumah tangga di Indonesia sehingga pemerintah perlu merencakan pasokan energi dengan matang agar tidak terjadi kelangkaan energi.

\section{Keterbatasan Penelitian}

1. Data mikro yang digunakan pada penelitian ini terbatas hanya 1 tahun saja (cross section). Jika memungkinkan ketersediaan series data maka sebaiknya dilakukan analisis data panel sehingga bisa dilakukan analisis yang lebih mendalam untuk melihat perubahan yang terjadi pada kurun waktu analisis.

2. Selain itu, hasil penelitian juga menunjukkan adanya perbedaan yang signifikan permintaan listrik pada wilayah perkotaan dan perdesaan. Penelitian selanjutnya bisa mempertimbangkan untuk membuat permodelan permintaan listrik untuk wilayah perkotaan dan perdesaan.

3. Penelitian ini melihat permintaan listrik berdasarkan harga barang itu sendiri, pendapatan per kapita, ukuran rumah tangga, umur kepala rumah tangga, tingkat pendidikan kepala rumah tangga, dan wilayah tempat tinggal. Sedangkan untuk efek harga barang lain tidak disertakan dalam penelitian ini sehingga penelitian selanjutnya dapat mengaitkan efek harga barang lain.

4. Penelitian ini tidak melakukan pengkategorian berdasarkan golongan pendapatan rumah tangga dan hanya menampilkan gambaran umum pengguna listrik 450 watt dan 900 watt sehingga penelitian ini tidak bisa mengkaji rumah tangga berdasarkan penerima subsidi dan non subsidi secara mendalam.

\section{DAFTAR PUSTAKA}

Adusah-Poku, F., \& Takeuchi, K. (2019). Household energy expenditure in Ghana: A doublehurdle model approach. World Development, 117, 266-277.

Azmi, R., \& Amir, H. (2014). Ketahanan energi: Konsep, kebijakan dan tantangan bagi Indonesia. Buletin Info Risiko FIskal, 1.

Badan Pusat Statistik. (2018). Statistik Kesejahteraan Rakyat 2018. Jakarta: BPS RI.

Badan Pusat Statistik. (2019a). Neraca Energi Indonesia 2014-2018. Jakarta: BPS RI.

Badan Pusat Statistik. (2019b). Konsep dan Definisi Susenas Maret 2018. Jakarta: BPS RI.

Brounen, D., Kok, N., \& Quigley, J. M. (2012). Residential energy use and conservation: Economics and demographics. European Economic Review, 56(5), 931-945.

Case, K. E., Fair, R. C., \& Oster, S. M. (2012). Principles of economics tenth edition. United State of America: Prentice Hall. 
Cao, J., Ho, M. S., \& Liang, H. (2016). Household energy demand in Urban China: Accounting for regional prices and rapid income change. The Energy Journal, 37, 87-110.

Daniel, M. (2001). Pengantar ekonomi pertanian. Jakarta: PT Bumi Aksara.

Deutsch, M., \& Timpe, P. (2013). The effect of age on residential energy demand. ECEEE Summer Study Proceedings pages, 2177-2188.

Doloksaribu, P. (2010). Analisa Keandalan Sistem Distribusi Tenaga Listrik. Jurnal Teknik Elektro Univ. Cendrawasih, 1(1), 20-25.

Estiri, H. (2015). The indirect role of households in shaping US residential energy demand patterns. Energy Policy, 86, 585-594.

Estiri, H., \& Zagheni, E. (2019). Age matters: Ageing and household energy demand in the United States. Energy Research \& Social Science, 55, 62-70.

Huebner, G. M., Hamilton, I., Chalabi, Z., Shipworth, D., \& Oreszczyn, T. (2015). Explaining domestic energy consumption-the comparative contribution of building factors, sociodemographics, behaviours and attitudes. Applied energy, 159, 589-600.

International Labor Organization. (2010). Ekonomi Informal di Indonesia: Ukuran, Komposisi dan Evolusi. Jakarta: ILO.

Kementrian Energi dan Sumber Daya Mineral. (2019a). Handbook of energy and economic statistics of Indonesia (final edition). Jakarta: KESDM.

Kementrian Energi dan Sumber Daya Mineral. (2019b). Statistik Ketenagalistrikan 2019. Jakarta: KESDM.

Lee, C. C., \& Lee, J. D. (2010). A panel data analysis of the demand for total energy and electricity in OECD countries. The Energy Journal, 31(1), 1-24.

Mensah, J. T., \& Adu, G. (2015). An empirical analysis of household energy choice in Ghana. Renewable and Sustainable Energy Reviews, 51, 1402-1411.

Nababan, T. S. (2015). Analysis of Household Characteristics Affecting the Demand of PLN's Electricity. An Observation on Small Households in City of Medan, Indonesia. Academic Journal of Economic Studies, 1(2), 79-92.

Nazer, M., \& Handra, H. (2016). Analisis konsumsi energi rumah tangga perkotaan di Indonesia: Periode Tahun 2008 dan 2011. Jurnal Ekonomi dan Pembangunan Indonesia, 16(2), 141-153.

Ngui, D., Mutua, J., Osiolo, H., \& Aligula, E. (2011). Household energy demand in Kenya: An application of the linear approximate almost ideal demand system (LA-AIDS). Energy Policy, 39(11), 7084-7094.

Pereira Uhr, D. de A., Squarize Chagas, A. L., \& Ziero Uhr, J. G. (2019). Estimation of elasticities for electricity demand in Brazilian households and policy implications. Energy Policy, 129, 69-79.

Perusahaan Listrik Negara. (2017). Inspiring Journey of Transformation: Laporan Tahunan 2017. Jakarta: PT PLN (Persero).

Ramadhani, A. W., and Munandar. A. I. (2017). Kemiskinan Anak di Provinsi DKI Jakarta: Susenas 2017 (Child Poverty in DKI Jakarta: Susenas 2017). Jurnal Ekonomi Kuantitatif Terapan, Vol. 12 (2), 111-123

Romadhoni, B., \& Akhmad, A. (2020). Household Electricity Demand in South Sulawesi, Indonesia. International Journal of Energy Economics and Policy, 10(4), 229.

Romero-Jordán, D., Peñasco, C., \&del Río, P. (2014). Analysing the determinants of household electricity demand in Spain. An econometric study. International Journal of Electrical Power \& Energy Systems, 63, 950-961.

Saepudin, T. (2018), Development of electricity program, electrificaty ratio with human development index in west java province, Indonesia. International Journal of Energy Economics and Policy, 8(1), 227-230. 
Salari, M., \& Javid, R. J. (2017). Modeling household energy expenditure in the United States. Renewable and Sustainable Energy Reviews, 69, 822-832.

Susanti, I., Syairozi, M. I., \& Lukman, H. Y. W. (2021). Analisis Sistem Manajemen Dalam Pengelolaan Bumdes Di Desa Bluluk. Jurnal Sains Sosio Humaniora, 5(2), 701-710.

Syairozi, M. I. (2017). Percepatan Pengurangan Kemiskinan Sektor Pertanian di Kabupaten Malang. In Seminar Nasional \& Call For Paper, FEB Unikama (pp. 145-155).

Wijaya, M. E., \& Tezuka, T. (2013). A comparative study of households' electricity consumption characteristics in Indonesia: A techno-socioeconomic analysis. Energy for Sustainable Development, 17(6), 596-604.

Zou, B., \& Luo, B. (2019). Rural household energy consumption characteristics and determinants in China. Energy, 182, 814-823. 